
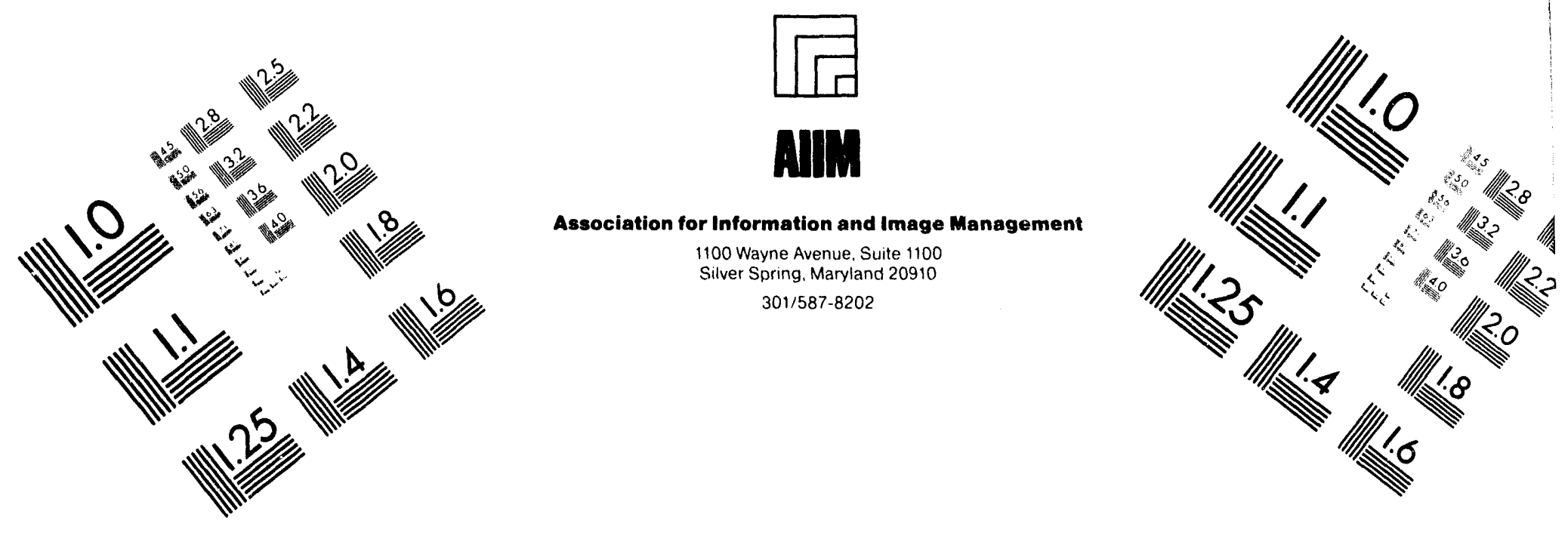

\title{
Centimeter
}

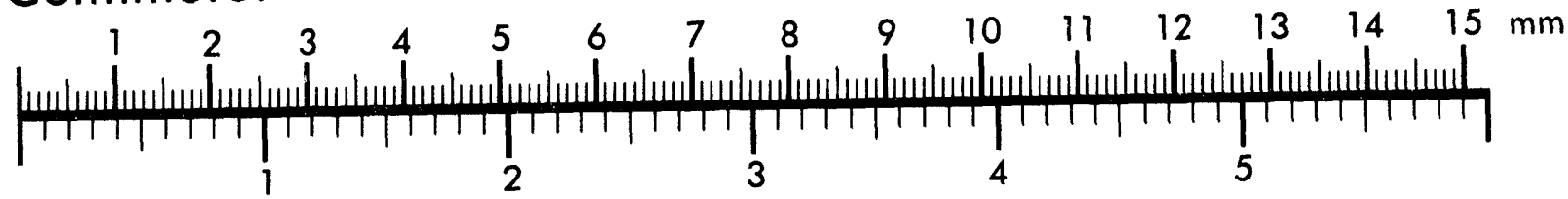
Inches
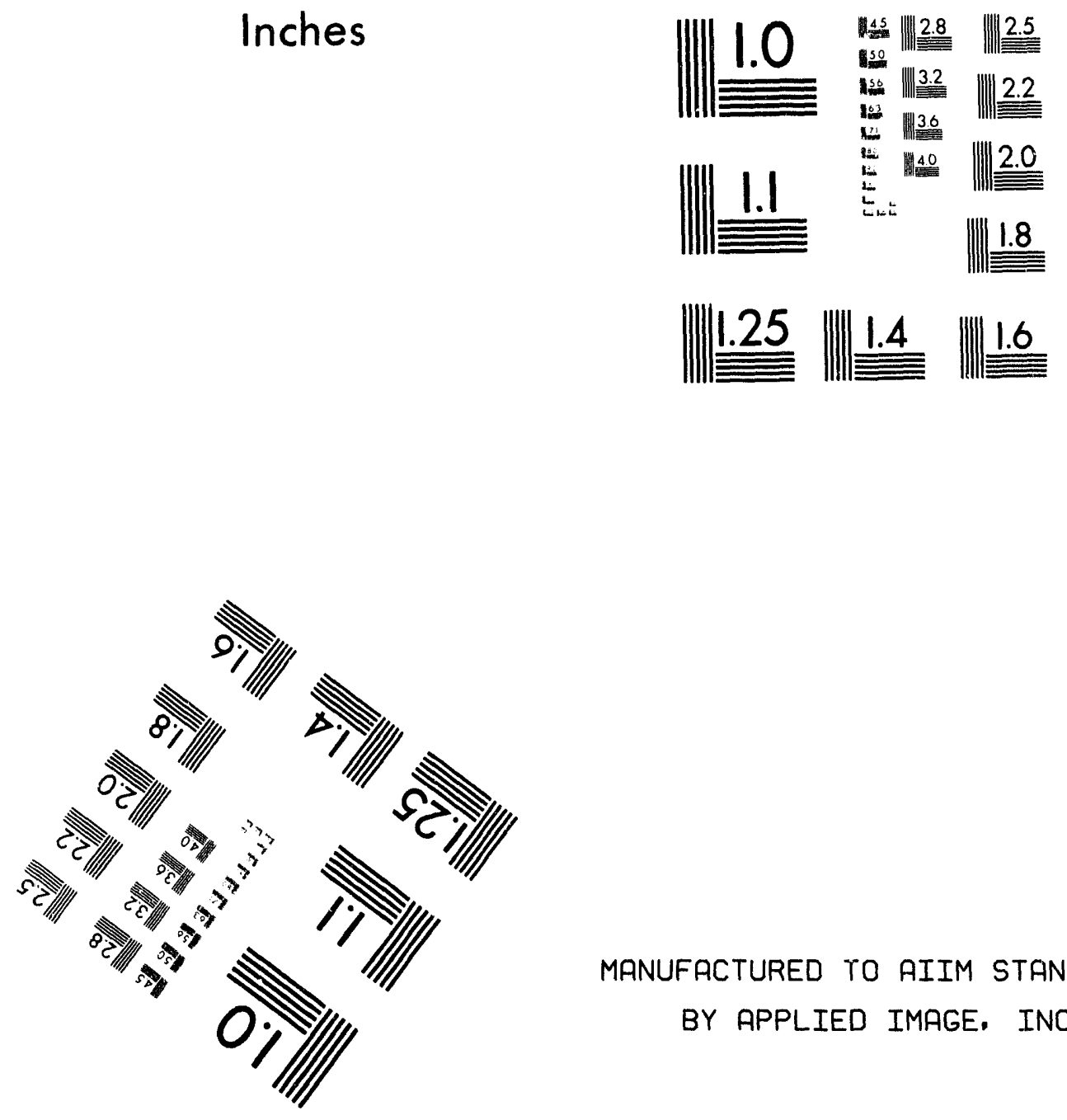

MANUFACTURED TO AIIM STANDARDS BY APPLIED IMAGE, INC.

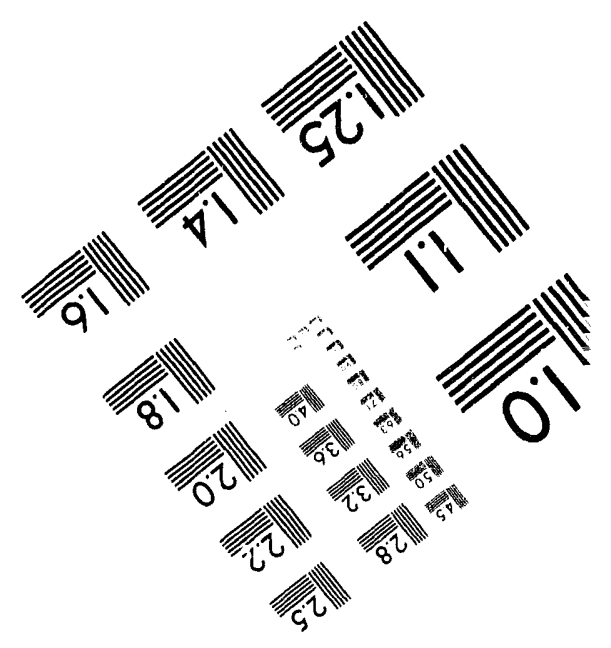



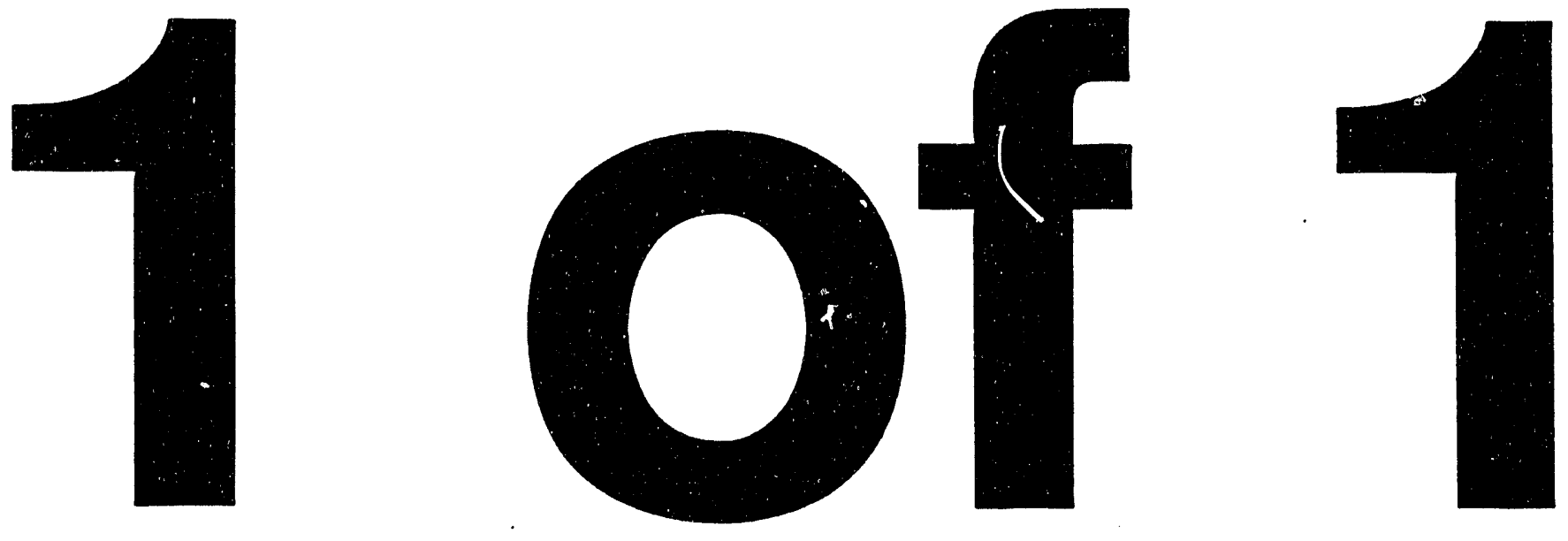


\title{
Chemical Technology Division
}

\section{CATALYZED REDUCTION OF NITRATE IN AQUEOUS SOLUTIONS}

\author{
P. A. Haas
}

Date Published - August 1994

Prepared by the

OAK RIDGE NATIONAL LABORATORY

Oak Ridge, Tennessee 37831 managed by MARTIN MARIETTA ENERGY SYSTEMS, INC. for the U.S. DEPARTMENT OF ENERGY under contract DE-AC05-84OR21400 


\section{CONTENTS}

EXECUTIVE SUMMARY $\ldots \ldots \ldots \ldots \ldots \ldots \ldots \ldots \ldots \ldots \ldots \ldots \ldots$

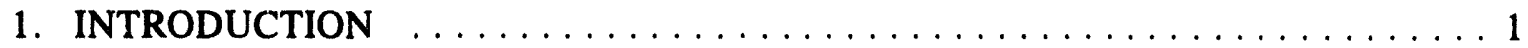

2. EXPERIMENTAL APPARATUS $\ldots \ldots \ldots \ldots \ldots \ldots \ldots \ldots \ldots \ldots \ldots$

3. INTERPRETATION OF RESULTS TO SHOW REACTIONS $\ldots \ldots \ldots \ldots \ldots 7$

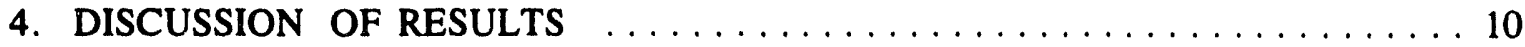

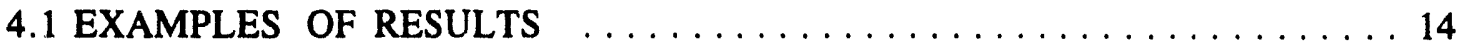

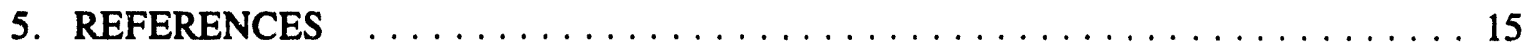

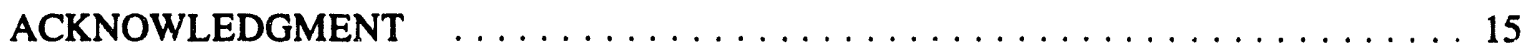




\section{EXECUTTVE SUMMARY}

The presence of sodium nitrate and other nitrate salts in wastes is a major source of difficulty for permanent disposal. A chemical reduction of nitrate using aluminum metal has been demonstrated, ${ }^{1}$ but $\mathrm{NH}_{3}$, hydrazine, or organic compounds containing oxygen would have important advantages for reduction of nitrate in sodium nitrate solutions. The objective of this seed money study was to determine the minimum conditions for reduction reactions. The proposed procedure was batchwise heating of aqueous solutions in closed vessels with monitoring of temperatures and pressures.

A simple and convenient apparatus and procedure was demonstrated for observation of the formation of gaseous products and the coilection of samples for analyses. The test conditions were limited to $250^{\circ} \mathrm{C}$ and $\sim 1000$ psi maximum as a result of the pressure rating of system components.

We did not find any useful reduction of sodium nitrate to sodium hydroxide as the primary product. The nitrate present at $\mathrm{pHs}<4$ as $\mathrm{HNO}_{3}$ or $\mathrm{NH}_{4} \mathrm{NO}_{3}$ is easily decomposed, and the effect of nitromethane at these low pHs (as reported in U.S. Patent $4,225,455)^{2}$ was confirmed. When acetic acid or formic acid was added, 21 to $56 \%$ of the nitrate in sodium nitrate solutions was reduced by methanol or formaldehyde to give sodium acetate, sodium carbonate, or sodium formate as products. With hydrazine and acetic acid, $73 \%$ of the nitrate was decomposed to convert $\mathrm{NaNO}_{3}$ to sodium acetate. With hydrazine and formic acid, $36 \%$ of the nitrate was decomposed. If these compounds are more acceptable for final disposal than sodium nitrate, the reagents are cheap and the conversion conditions would be practical for easy use. The use of ammonium acetate or formate salts did not give significant reductions of the nitrate in sodium nitrate solutions.

\section{INTRODUCTION}

The presence of nitrate salts in wastes is a major source of difficulty for permanent disposal. Inorganic nitrates are soluble and are very difficult to immobilize so that leaching will not occur. After the tank wastes at U.S. Department of Energy (DOE) plant sites are treated to remove the predominant radionuclides, then the $\mathrm{NaNO}_{3}$ and $\mathrm{KNO}_{3}$ are controlling requirements for disposal of the bulk of the wastes. Thermal decompositions of waste 
with high $\mathrm{NaNO}_{3}-\mathrm{KNO}_{3}$ contents require excessive temperatures $\left(>1000^{\circ} \mathrm{C}\right)$ and give viscous melts with poor properties for transfer or disposal.

One type of disposal treatment to lower nitrates concentration is chemical reductions. For acidic solutions, chemical reductions have been demonstrated and applied using organic compounds containing oxygen (formaldehyde, sugar, methanol, etc.), ammonia, and hydrazine. These reducing agents give high rates of reaction for high nitric acid concentrations and much lower or zero rates in caustic solutions.

One treatment currently recommended for caustic waste solutions is the reduction of $\mathrm{NaNO}_{3}$ and $\mathrm{KNO}_{3}$ by aluminum metal to give $\mathrm{NH}_{3}$ and a mixture of hydrous aluminum oxides, $\mathrm{NaOH}$, and sodium aluminates.' Experimental results show that an excess of aluminum metal is required as it also reduces water to form hydrogen. The aqueous product slurry can be calcined to convert the sodium aluminates to insoluble $\mathrm{Al}_{2} \mathrm{O}_{3}$ and $\mathrm{NaOH}$. These experimental results show that $1 \mathrm{~kg}$ of $\mathrm{NaNO}_{3}$ will produce about $3.5 \mathrm{~kg}$ of $\mathrm{Al}_{2} \mathrm{O}_{3}+\mathrm{NaOH}$. Control and safe operation of the process require the controlled removal of the large heat of reaction and disposal of $\mathrm{NH}_{3}$ and $\mathrm{H}_{2}$.

For the following reasons, either $\mathrm{NH}_{3}$, hydrazine, or organic compounds containing oxygen would have important advantages for the reduction of nitrate in caustic solutions:

1. They are much cheaper than aluminum metal.

2. They do not reduce water to $\mathrm{H}_{2}$ and nitrate to $\mathrm{NH}_{3}$; the $\mathrm{H}_{2}$ and $\mathrm{NH}_{3}$ are disposal problems as well as wasted reduction capacity.

3. The amount of nonvolatile products is much smaller. They could convert $1 \mathrm{~kg}$ of $\mathrm{NaNO}_{3}$ to $0.47 \mathrm{~kg}$ of $\mathrm{NaOH}$, while aluminum metal gives $3.5 \mathrm{~kg}$ of $\mathrm{NaOH}+\mathrm{Al}_{2} \mathrm{O}_{3}$.

4. A smaller heat of reaction is favorable to easier control of the process reactions. There are no experimental data to show practical reductions of $\mathrm{NaNO}_{3}$ to $\mathrm{NaOH}$ by ammonia, hydrazine, or organic compounds. When acidic solutions were reacted, the reductions stopped before the boiling solutions became caustic.

One important experimental result (U.S. Patent 4,225,455) shows much faster and more complete decompositions of $\mathrm{NH}_{4} \mathrm{NO}_{3}$ solutions or $\mathrm{UO}_{2}\left(\mathrm{NO}_{3}\right)_{2}$ solutions when nitromethane was added. ${ }^{2}$ The demonstrated reactions were $>99 \%$ of the $\mathrm{NH}_{4}$ in $\mathrm{NH}_{4} \mathrm{NO}_{3}$ $\mathrm{HNO}_{3}$ and 98 to $99 \%$ reduction of the nitrate in $\mathrm{UO}_{2}\left(\mathrm{NO}_{3}\right)_{2}-\mathrm{NH}{ }_{4} \mathrm{NO}_{3}$ solution. The first solution remained acidic (from excess $\mathrm{HNO}_{3}$ ), and the second showed a final $\mathrm{pH}$ of 3.1 . 
The minimum temperatures to start the reactions decreased about $80^{\circ} \mathrm{C}$ (from $\sim 190$ to $\sim 110^{\circ} \mathrm{C}$ ). One possible explanation for this now efficient reaction is that the nitromethane might be a catalyst. Another explanation would be that it initiated a chain reaction, but this does not fully explain why the reactions were much less complete without nitromethane.

Thermochemical considerations. Thermodynamic data can be applied for reduction reactions to determine the thermodynamic feasibility. The reductions of nitrate and the oxidations of organics can give many different products; a failure to consider the more favorable reactions can lead to false conclusions. Thirteen reactions of interest to this discussion are listed along with the free energies of reaction at $25^{\circ} \mathrm{C}$ in $\mathrm{kJ} / \mathrm{mol} \mathrm{NaNO}{ }_{3}$ (Table 1). The NAC process reduction of $\mathrm{NaNO}_{3}$ in caustic solution ${ }^{1}$ can be represented by Eq. (1). The nonproductive reduction of water is less energetic for the same amount of $\mathrm{Al}$ [Eq. (2)], but is also a very exothermic reaction. For the chemical reducing compounds considered in this study, the free energies of reaction are more favorable (more negative) in the order of ammonium salts, methyl alcohol, formaldehyde, and hydrazine. The difference in free energies for $\mathrm{Na}_{2} \mathrm{CO}_{3}$ vs sodium formate as products is small [see Eqs. (8) and (8A)]. Reactions (6) and (7) are not very favorable, and the high vapor pressure of $\mathrm{NH}_{3}$ over hot caustic solutions is unfavorable for reaction (3).

\section{EXPERIMENTAL APPARATUS}

The experimental apparatus and procedures were designed to contain small batches of reactants and products under pressure with indications of the pressures and temperatures during heatup in a furnace to $250^{\circ} \mathrm{C}$ maximum. The system components were selected to allow pressures up to $1800 \mathrm{psi}$. The system included a rupture disk rated for $1200 \mathrm{psi}$. The vapor pressure of water at $250^{\circ} \mathrm{C}$ is $580 \mathrm{psia}$. The amounts of solution and reac'ants as compared to the total volume were selected to ensure a residue of solution at all test conditions and pressures $<1000$ psi for complete reduction of all nitrate to gaseous products.

The apparatus is shown as a schematic diagram (Fig. 1) and a photograph (Fig. 2). The reactor was a 304 stainless steel gas cylinder rated at $1800 \mathrm{psi}$ at -320 to $600^{\circ} \mathrm{C}$. This cylinder had a capacity of $150 \mathrm{~mL}$ and 1/4-in. NPS female pipe threads in each end. An 
Table 1. Reactions for chemical reductions of nitrate in $\mathrm{NaNO}_{3}$ solutions

\begin{tabular}{|c|c|c|}
\hline $\begin{array}{l}\text { Equation } \\
\text { No. }\end{array}$ & Chemical equation & $\begin{array}{l}\text { Free energy of reaction at } 298 \mathrm{~K} \\
\left.(\mathrm{~kJ} / \mathrm{mol} \mathrm{NaNO})_{3}\right)\end{array}$ \\
\hline (1) & $6 \mathrm{NaNO}_{3}+16 \mathrm{Al}+12 \mathrm{H}_{2} \mathrm{O} \rightarrow 6 \mathrm{NaOH}+8 \mathrm{Al}_{2} \mathrm{O}_{3}+6 \mathrm{NH}_{3}$ & -1673 \\
\hline (2) & $2 \mathrm{Al}+3 \mathrm{H}_{2} \mathrm{O} \rightarrow \mathrm{Al}_{2} \mathrm{O}_{3}+3 \mathrm{H}_{2}$ & $-1134($ per $16 / 6 \mathrm{Al})$ \\
\hline (3) & $\mathrm{NaNO}_{3}+\mathrm{NH}_{4} \mathrm{OH} \rightarrow \mathrm{NaOH}+\mathrm{N}_{2} \mathrm{O}+\mathrm{H}_{2} \mathrm{O}$ & -162 \\
\hline (4) & $2 \mathrm{NaNO}_{3}+\mathrm{CH}_{3} \mathrm{OH} \rightarrow \mathrm{Na}_{2} \mathrm{CO}_{3}+2 \mathrm{NO}+2 \mathrm{H}_{2} \mathrm{O}$ & -216 \\
\hline (5) & $2 \mathrm{NaNO}_{3}+2 \mathrm{HCHO} \rightarrow \mathrm{Na}_{2} \mathrm{CO}_{3}+\mathrm{N}_{2} \mathrm{O}+2 \mathrm{H}_{2} \mathrm{O}+\mathrm{CO}_{2}$ & -425 \\
\hline (6) & $\mathrm{NaNO}_{3}+\mathrm{NH}_{4}\left(\mathrm{CHO}_{2}\right) \rightarrow \mathrm{Na}\left(\mathrm{CHO}_{2}\right)+\mathrm{N}_{2} \mathrm{O}+2 \mathrm{H}_{2} \mathrm{O}$ & -110 \\
\hline (7) & $\mathrm{NaNO}_{3}+\mathrm{NH}_{4}\left(\mathrm{C}_{2} \mathrm{H}_{3} \mathrm{O}_{2}\right) \rightarrow \mathrm{Na}\left(\mathrm{C}_{2} \mathrm{H}_{3} \mathrm{O}_{2}\right)+\mathrm{N}_{2} \mathrm{O}+2 \mathrm{H}_{2} \mathrm{O}$ & -128 \\
\hline (8) & $2 \mathrm{NaNO}_{3}+\mathrm{CH}_{3} \mathrm{OH}+2 \mathrm{HCOOH} \rightarrow \mathrm{Na}_{2} \mathrm{CO}_{3}+2 \mathrm{NO}+4 \mathrm{H}_{2} \mathrm{O}+2 \mathrm{CO}$ & -244 \\
\hline$(8 \mathrm{~A})$ & $2 \mathrm{NaNO}_{3}+\mathrm{CH}_{3} \mathrm{OH}+2 \mathrm{HCOOH} \rightarrow 2 \mathrm{Na}\left(\mathrm{CHO}_{2}\right)+2 \mathrm{NO} \rightarrow 3 \mathrm{H}_{2} \mathrm{O}+\mathrm{CO}_{2}$ & -268 \\
\hline (9) & $2 \mathrm{NaNO}_{3}+\mathrm{CH}_{3} \mathrm{OH}+2 \mathrm{CH}_{3} \mathrm{COOH} \rightarrow 2 \mathrm{Na}\left(\mathrm{C}_{2} \mathrm{H}_{3} \mathrm{O}_{2}\right)+2 \mathrm{NO}+3 \mathrm{H}_{2} \mathrm{O}+\mathrm{CO}_{2}$ & -267 \\
\hline (10) & $2 \mathrm{NaNO}_{3}+2 \mathrm{HCHO}+2 \mathrm{HCOOH} \rightarrow \mathrm{Na}_{2} \mathrm{CO}_{3}+\mathrm{N}_{2} \mathrm{O}+4 \mathrm{H}_{2} \mathrm{O}+\mathrm{CO}_{2}+2 \mathrm{CO}$ & -477 \\
\hline (11) & $2 \mathrm{NaNO}_{3}+2 \mathrm{HCHO}+2 \mathrm{CH}_{3} \mathrm{COOH} \rightarrow 2 \mathrm{Na}\left(\mathrm{C}_{2} \mathrm{H}_{3} \mathrm{O}_{2}\right)+\mathrm{N}_{2} \mathrm{O}+3 \mathrm{H}_{2} \mathrm{O}+2 \mathrm{CO}_{2}$ & -477 \\
\hline (12) & $4 \mathrm{NaNO}_{3}+5 \mathrm{~N}_{2} \mathrm{H}_{5} \mathrm{OH} \rightarrow 4 \mathrm{NaOH}+7 \mathrm{~N}_{2}+13 \mathrm{H}_{2} \mathrm{O}$ & -680 \\
\hline (13) & $4 \mathrm{NaNO}_{3}+5 \mathrm{~N}_{2} \mathrm{H}_{5} \mathrm{OH}+4 \mathrm{CH}_{3} \mathrm{COOH} \rightarrow 4 \mathrm{Na}\left(\mathrm{C}_{2} \mathrm{H}_{3} \mathrm{O}_{2}\right)+7 \mathrm{~N}_{2}+17 \mathrm{H}_{2} \mathrm{O}$ & -760 \\
\hline
\end{tabular}


ORNL DWG 93A-952R

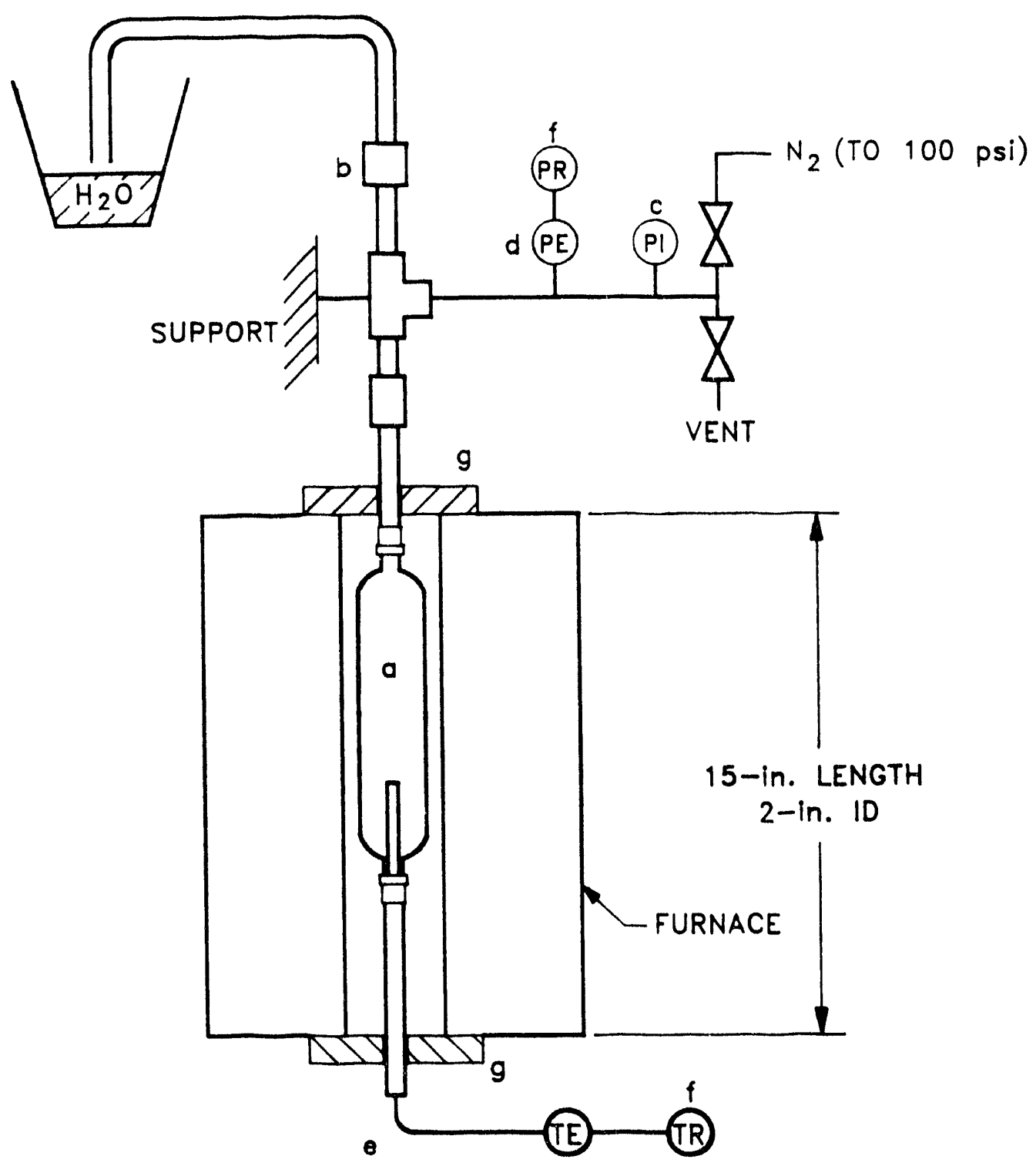

a GAS CYLINDER (304 STAINLESS STEEL) MATHESON MODEL 4HD150 (RATED FOR 1800 psi)

b RUPTURE DISK (1200 psi)

c PRESSURE GAGE $(0-1000)$

d PRESSURE TRANSDUCER

a THERMOCOUPLE

$f$ TWO-PEN RECORDER (STRIP CHART)

$g$ INSULATION (TOP-SPLIT; BOTTOM-ATTACHED WITH HOLE)

Fig. 1. Equipment for studies of reduction of nitrate in solutions. 


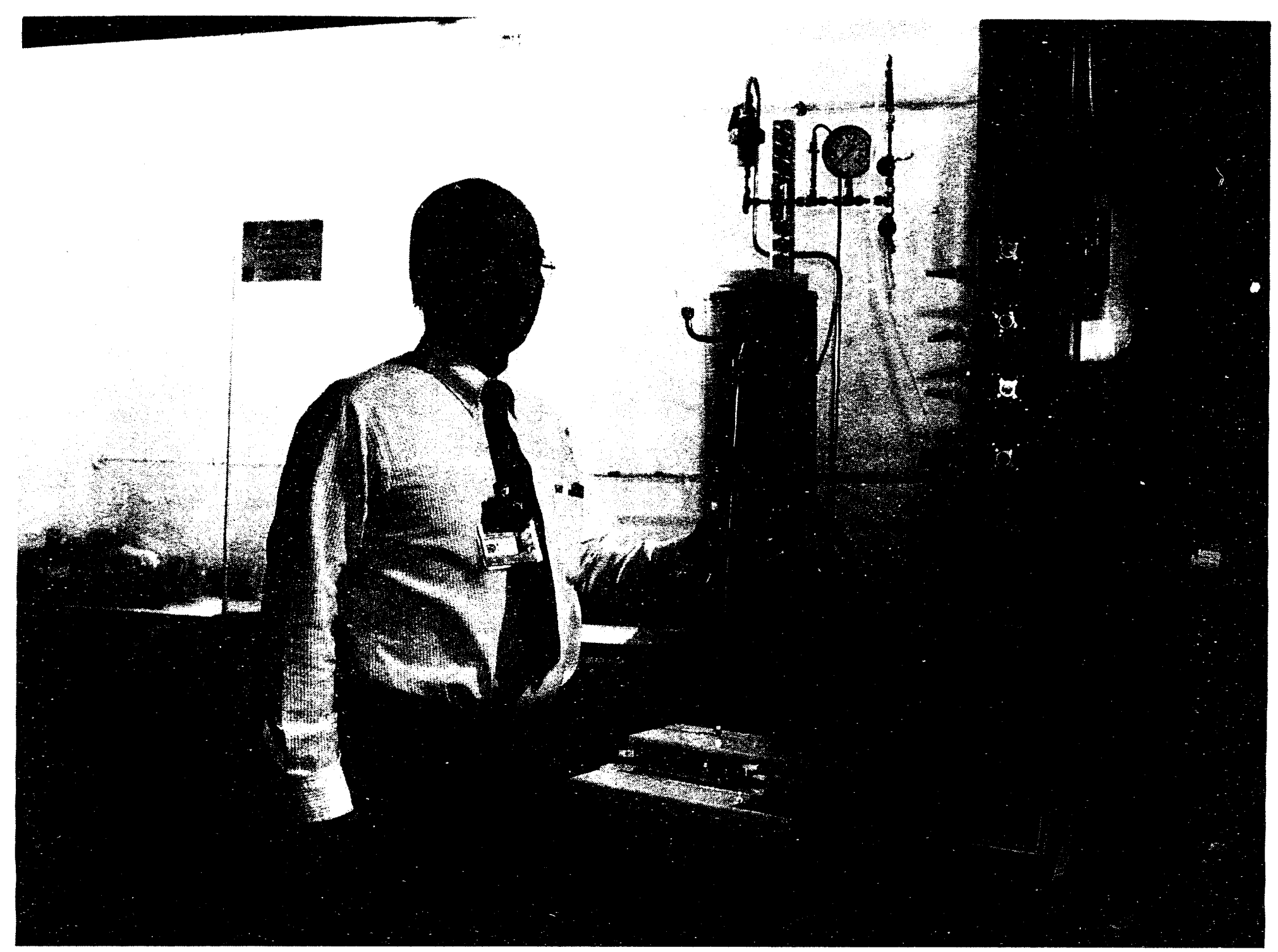

Fig. 2. A photograph of the CRON apparatus. 
initial aqueous solution volume of 30 to $40 \mathrm{~mL}$ and 80 to $100 \mathrm{mmol}$ maximum of natrate were selected to meet the criteria given above. A pressurization to 60 to 90 psig with $\mathrm{N}_{2}$ was selected to give a low partial pressure of $\mathrm{O}_{2}$ and to fill the connections outside the furnace with noncondensible gases at the maximum test pressures. The 30 to $40 \mathrm{~mL}$ of solution was adequate for easy material balances and samples for analyses or titration.

\section{INTERPRETATION OF RESULTS TO SHOW REACTIONS}

The chemical reactions are indicated by several different results. The experimental measurements included the amounts of material charged to the test, the amounts of material removed after cooldown to room temperatures, the power setting for the furnace, the temperatures and the pressures throughout the test, and chemical analyses of the product solution. The most useful indications of chemical reactions were as follows:

1. The product solutions were analyzed for nitrate and sodium. The nitrate-to-sodium ratio, as compared to that in the charge, indicated what fraction of the nitrate was unreacted. This comparison was better than a nitrate material balance because the ratio would be independent of the weight or volume losses as gaseous products, leaks, or incomplete recovery. The sodium analyses were compared with material balance results as a check for gross errors.

2. The formation of gaseous products was indicated by the pressure in excess of the pressure for a test without reaction. The best indications were for test conditions that were otherwise as identical as possible. The most common conditions used were about $45 \mathrm{~g}$ of solution charge, $\mathrm{N}_{2}$ to 82 psig at $22^{\circ} \mathrm{C}$, furnace power setting of $29 \%$, placement of insulation to give reproducible openings or gaps, and temperatures and pressures read from indicators (a pressure gage and a digital temperature indicator for the thermocouple in the well exposed to solution).

The most accurate and sensitive excess pressures were from comparisons at the same temperature (Figs. 3 and 4). Comparisons at the same run time after the start of furnace power was less accurate because the heat from chemical reactions and the heat losses through gaps in the insulation were variable. 
ORNL DWG 94A-428

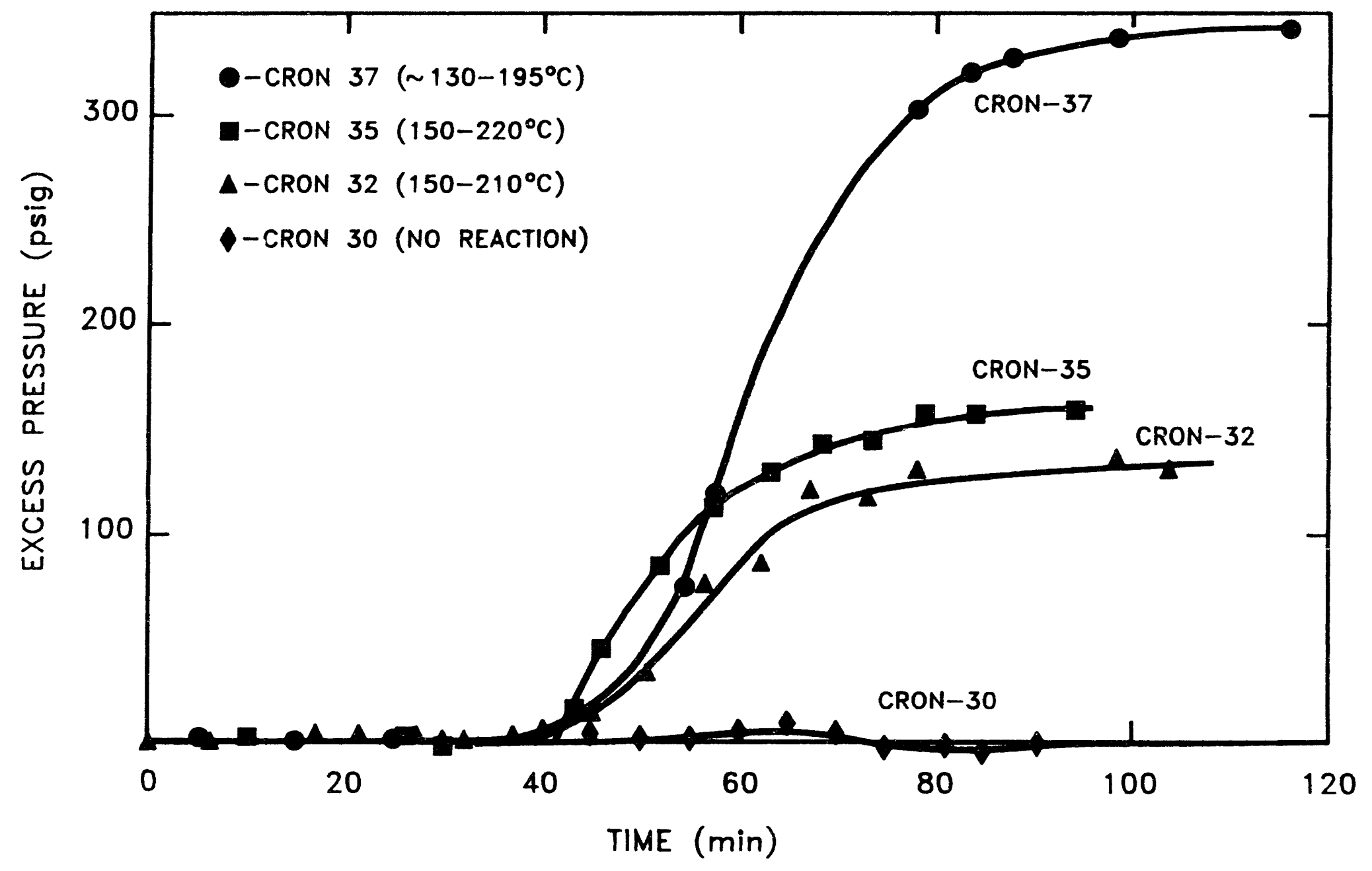

Fig. 3. Excess pressures from gaseous products of reactions. 
ORNL DWG 94A-429

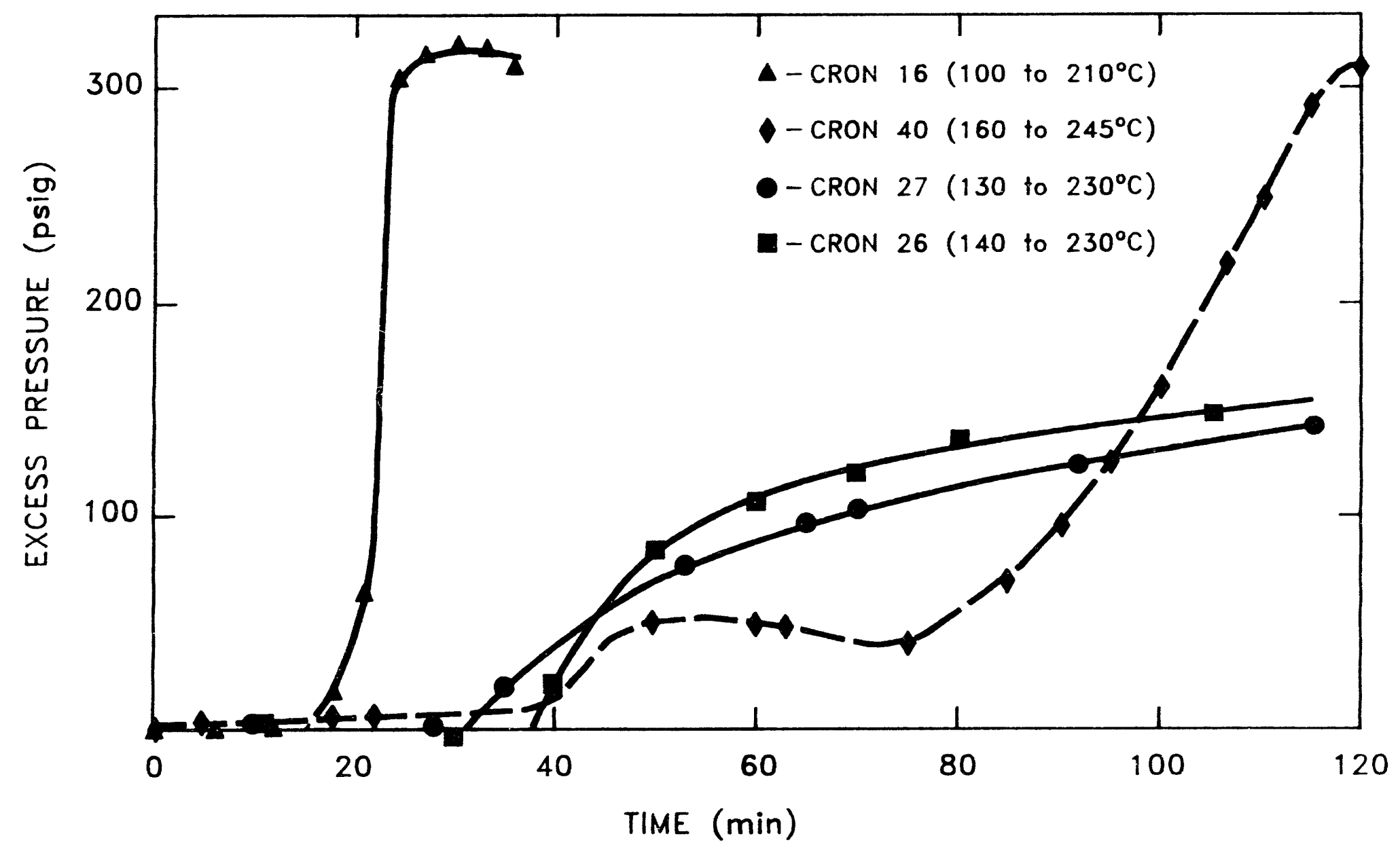

Fig. 4. Additional excess pressures from gaseous products of reactions. 
3. The solution weight loss was a measure of the weight of volatile products. This indication had two serious errors: losses as leaks or incomplete recovery and reactions to give volatile products without reaction of nitrate. For example, sodium formate can decompcse to form sodium carbonate, carbon dioxide, and hydrogen without any reduction of nitrate.

4. The amount of gas minus the gas charged was a measure of the amount of reaction. Calculations to correct for vapor pressures and temperature would be difficult. The excess pressure as described above was equivalent to an empirical vapor pressure and temperature correction. The pressure after cooldown to room temperature did not require such corrections, but small leaks were a serious source of errors. As mentioned above, decomposition of sodium formate or other reactions can also give gaseous products.

Some other possible indications of chemical reactions were not very useful. The heat effects of the chemical reactions were usually small compared to tha heat input from the furnace and the heat capacity of the reactor vessel. Very high rates ci reaction were detectable as blips on the temperature recorder chart, but temperature effects were otherwise not useful. For test conditions intended to convert sodium nitrate to sodium hydroxide, product solution samples were titrated with $\mathrm{HCl}$ solutions. Tests with blanks indicated that graphs of $\mathrm{pH}$ vs amounts of $\mathrm{HCl}$ would give measures of the amounts of $\mathrm{NaOH}, \mathrm{Na}_{2} \mathrm{CO}_{3}$, and $\mathrm{NaHCO}_{3}$ present. The product pHs and the titrations both showed negligible conversions of $\mathrm{NaNO}_{3}$ to $\mathrm{NaOH}$ or $\mathrm{Na}_{2} \mathrm{CO}_{3}$. The test conditions with mixtures of organic acids, ammonium compounds, and methyl alcohol or formaldehyde introduced too many variables to allow identification of products by titration.

\section{DISCUSSION OF RESULTS}

The charge variables for the tests were the reducing constituents $\left(\mathrm{CH}_{3} \mathrm{OH}, \mathrm{HCHO}\right.$, sugar, $\mathrm{NH}_{4}{ }^{+}$, and $\mathrm{N}_{2} \mathrm{H}_{5} \mathrm{OH}$ ); the absence or presence of $\mathrm{CH}_{3} \mathrm{NO}_{2}$ or a platinum gauze as catalysts; and the presence or absence of acetate, formate, or phosphate to form their sodium salts as products. In the absence of the acetate, formate, or phosphate, the sodium products after reduction of nitrate would be caustic (either $\mathrm{NaOH}$ or $\mathrm{Na}_{2} \mathrm{CO}_{3}$ ) solutions. 
The chemical analyses of product solutions were the most important verification of nitrate destruction (Table 2). The excess pressure was a good measure of the formation of gaseous products (Table 3), but the amount of gases varied with the products of nitrate reduction $\left(\mathrm{N}_{2}, \mathrm{~N}_{2} \mathrm{O}\right.$, NO, etc.) and with other reactions, such as the decomposition of sodium formate or ammonium salts. Near room temperature, high pressures of $\mathrm{CO}_{2}$ gave large solubilities in the solution. The weight losses commonly showed about $25 \%$ more reaction of nitrate than the chemical analyses or excess gas pressures (Tables 2 and 3). These differences also occurred for tests with no reaction and were probably the losses $(\sim 1 \mathrm{~g} /$ test $)$ as vapor, leaks, and unrecovered solution.

Most of the test results that showed reductions of nitrate by chemical analyses (Table 2) gave product solution pHs of 3.62 to 4.99 (Table 3). These reductions of nitrate were by $\mathrm{CH}_{3} \mathrm{OH}, \mathrm{HCHO}$, or $\mathrm{N}_{2} \mathrm{H}_{5} \mathrm{OH}$ with some acetic or formic acid in solutions. Test results showed that sodium acetate was stable and that there was no reduction of nitrate by ammonium acetate-acetic acid. For $\mathrm{NaNO}_{3}$-ammonium formate-formic acid solution, chemical analyses showed a small (perhaps not significant) loss of nitrate, but gaseous products were formed - probably by decomposition of formate.

The catalyzed decomposition of $\mathrm{NH}_{4} \mathrm{NO}_{3}$ to water and $\mathrm{N}_{2} \mathrm{O}$ in acidic solutions was confirmed. But ammonium acetate-acetic acid or ammonium formate-formic acid did not reduce $\mathrm{NaNO}_{3}$ to form the acetate or formate salts. Combinations of $\mathrm{CH}_{3} \mathrm{OH}$ or HCHO with acetic acid or formic acid gave 21 to $56 \%$ reductions of the nitrate in sodium nitrate solutions (Table 2). Both $\mathrm{CH}_{3} \mathrm{OH}$ and $\mathrm{HCHO}$ showed detectable rates of reaction at starting temperatures of 120 to $150^{\circ} \mathrm{C}$ and high rates at 150 to $160^{\circ} \mathrm{C}$. The catalytic effects of $\mathrm{CH}_{3} \mathrm{NO}_{2}$ or Pt were not observed but were only tested for one set $\left(\mathrm{CH}_{3} \mathrm{OH}-\right.$ acetic acid) of these charge compositions.

The tests with hydrazine show more reduction of the nitrate in sodium nitrate solutions than the reductions by $\mathrm{CH}_{3} \mathrm{OH}$ or $\mathrm{HCHO}$. Hydrazine alone gave $29 \%$ reductions of the nitrate. The product was probably $\mathrm{NaOH}$. Hydrazine and acetic acid gave $73 \%$ reduction of nitrate and a product solution $\mathrm{pH}$ of 6.70 . Hydrazine and formic acid gave similar formation of gaseous products, but only $36 \%$ reduction of the nitrate. Most of the gas was probably from decomposition of sodium formate.

The sugar and phosphates have undesirable characteristics that make them less promising than the alternate reducing compounds. The sugar easily decomposes or 
Table 2. A summary of major test results for reductions of nitrate in aqueous solutions

\begin{tabular}{|c|c|c|c|c|c|c|c|c|}
\hline $\begin{array}{l}\text { Test } \\
\text { No. }\end{array}$ & $\begin{array}{l}\text { Equation } \\
\text { from } \\
\text { Table } 1\end{array}$ & $\begin{array}{l}\text { Charge } \mathrm{NO}_{3}^{-} / \mathrm{Na} \\
\text { ratio }(\mathrm{mol} / \mathrm{mol})\end{array}$ & $\begin{array}{c}\text { Charge } \\
\text { pH }\end{array}$ & $\begin{array}{l}\text { Reducing } \\
\text { compound }\end{array}$ & $\begin{array}{l}\text { Intended sodium } \\
\text { product }\end{array}$ & $\begin{array}{l}\text { Catalyst } \\
\text { present }\end{array}$ & $\begin{array}{c}\mathrm{NO}_{3}^{-} \text {reduced } \\
\text { from analyses } \\
(\%)\end{array}$ & Comments \\
\hline 16 & & 2.09 & 6.6 & $\mathrm{CH}_{3} \mathrm{OH}$ & $\mathrm{Na}_{2} \mathrm{CO}_{3}$ & $\mathrm{CH}_{3} \mathrm{NO}_{2}$ & 46 & $\mathrm{HNO}_{3}$ and $\mathrm{NH}_{4} \mathrm{NO}_{3}$ decomposed \\
\hline 40 & (13) & 1.00 & 6.14 & $\mathrm{~N}_{2} \mathrm{H}_{5} \mathrm{OH}$ & $\mathrm{NaC}_{2} \mathrm{H}_{3} \mathrm{O}_{2}$ & $\mathrm{CH}_{3} \mathrm{NO}_{2}$ & 73 & \\
\hline 32 & (5) & 0.88 & 3.74 & НСНО & $\mathrm{Na}_{2} \mathrm{CO}_{3}$ & None & 56 & \\
\hline 26 & (9) & 1.00 & 1.78 & $\mathrm{CH}_{3} \mathrm{OH}$ & $\mathrm{NaC}_{2} \mathrm{H}_{3} \mathrm{O}_{2}$ & $\mathrm{Pt}, \mathrm{CH}_{3} \mathrm{NO}_{2}$ & 40 & \\
\hline 41 & & 1.00 & 5.56 & $\mathrm{~N}_{2} \mathrm{H}_{5} \mathrm{OH}$ & $\mathrm{Na}_{2} \mathrm{CO}_{3}$ & $\mathrm{CH}_{3} \mathrm{NO}_{2}, \mathrm{PI}$ & 36 & \\
\hline 35 & (11) & 1.00 & 1.67 & HCHO & $\mathrm{NaC}_{2} \mathrm{H}_{3} \mathrm{O}_{2}$ & $\mathrm{CH}_{3} \mathrm{NO}_{2}$ & 32 & \\
\hline 39 & (12) & 1.00 & 10.0 & $\mathrm{~N}_{2} \mathrm{H}_{5} \mathrm{OH}$ & $\mathrm{NaOH}$ & $\mathrm{CH}_{3} \mathrm{NO}_{2}$ & 29 & \\
\hline 27 & (9) & 1.00 & 1.81 & $\mathrm{CH}_{3} \mathrm{OH}$ & $\mathrm{NaC}_{2} \mathrm{H}_{3} \mathrm{O}_{2}$ & None & 26 & \\
\hline 34 & $(8 \mathrm{~A})$ & 100 & 1.11 & $\mathrm{CH}_{3} \mathrm{OH}$ & $\mathrm{NaCHO}_{2}$ & None & 22 & \\
\hline 37 & (10) & 0.94 & 1.84 & НСНо & $\mathrm{Na}_{2} \mathrm{CO}_{3}$ & None & $2 !$ & \\
\hline 33 & (6) & 1.00 & 4.12 & $\mathrm{NH}_{4} \mathrm{CHO}_{2}$ & $\mathrm{NaCHO}_{2}$ & $\mathrm{CH}_{3} \mathrm{NO}_{2}$ & $\leq 5$ & \\
\hline 31 & (5) & 1.00 & 1.76 & НСHO & $\mathrm{Na}_{2} \mathrm{CO}_{3}$ & None & 0 & $\mathrm{NaCHO}_{2}$ decomposed \\
\hline 30 & (7) & 1.00 & 5.8 & $\mathrm{NH}_{4} \mathrm{C}_{2} \mathrm{H}_{3} \mathrm{O}_{2}$ & $\mathrm{NaC}_{2} \mathrm{H}_{3} \mathrm{O}_{2}$ & $\mathrm{CH}_{3} \mathrm{NO}_{2}$ & 0 & No gas formation \\
\hline 36 & & $\mathbf{0}$ & 6.16 & None & $\mathrm{NaC}_{2} \mathrm{H}_{3} \mathrm{O}_{2}$ & & & No $\mathrm{NaNO}_{3}$ \\
\hline 29 & & 1.00 & 6.55 & None & $\mathrm{NaNO}_{3}$ & None & 0 & $\mathrm{NaNO}_{3}$ only \\
\hline 28 & (7) & 1.00 & 5.55 & $\mathrm{NH}_{4} \mathrm{C}_{2} \mathrm{H}_{3} \mathrm{O}_{2}$ & $\mathrm{NaC}_{2} \mathrm{H}_{3} \mathrm{O}_{2}$ & $\mathbf{P t}$ & 0 & No gas formation \\
\hline
\end{tabular}


Table 3. Complete product measurements for selected CRON tests

\begin{tabular}{|c|c|c|c|c|c|c|c|c|}
\hline \multirow{2}{*}{$\begin{array}{l}\text { Test } \\
\text { No. }\end{array}$} & \multicolumn{2}{|c|}{ Chemical analyses } & \multirow{2}{*}{$\begin{array}{l}\text { Product } \\
\text { pH }\end{array}$} & \multicolumn{3}{|c|}{ Excess gas pressure } & \multirow{2}{*}{$\begin{array}{l}\text { Calculated } \mathrm{NO}_{3}^{-} \\
\text {reduced from excess } \\
\text { pressure (\%) }\end{array}$} & \multirow{2}{*}{$\begin{array}{l}\text { Calculated } \mathrm{NO}_{3}^{-} \\
\text {reduced from } \\
\text { weight loss (\%) }\end{array}$} \\
\hline & $\begin{array}{l}\mathrm{NO}_{3}-/ \mathrm{Na} \\
(\mathrm{mol} / \mathrm{mol})\end{array}$ & $\begin{array}{c}\mathrm{Na} \text { out/Na in } \\
(\%)\end{array}$ & & (psi) & $\begin{array}{l}\text { Initial temp } \\
\left({ }^{\circ} \mathrm{C}\right)\end{array}$ & $\begin{array}{l}\text { Maximum } \\
\text { reaction }\left({ }^{\circ} \mathrm{C}\right)\end{array}$ & & \\
\hline 16 & 1.13 & Leak & 4.81 & 305 & 100 & 130 & 44 & Leak \\
\hline 26 & 0.60 & 98 & 4.63 & $>150$ & 140 & 150 & 33 & 46 \\
\hline 27 & 0.74 & 104 & 4.46 & $>150$ & 130 & 150 & 49 & 58 \\
\hline 28 & 1.01 & 112 & 5.01 & 0 & None & & 0 & 35 \\
\hline 29 & 0.98 & & 8.45 & 0 & None & & 0 & $<0$ \\
\hline 30 & 0.96 & 110 & 5.00 & 0 & None & & 0 & 34 \\
\hline 31 & 1.08 & 92 & 5.39 & 160 & 150 & 200 & 69 & 100 \\
\hline 32 & 0.39 & 92 & 4.99 & 135 & 150 & 190 & 55 & 95 \\
\hline 33 & 0.95 & 95 & 8.26 & $>200$ & 195 & 230 & 85 & 77 \\
\hline 34 & 0.78 & 95 & 3.62 & $>200$ & 120 & 160 & 69 & 93 \\
\hline 35 & 0.68 & 101 & 4.19 & 160 & 150 & 160 & 49 & 73 \\
\hline 36 & & & 6.09 & 0 & None & & 0 & -0 \\
\hline 37 & 0.74 & 95 & 3.56 & 350 & 130 & 180 & 68 & 84 \\
\hline 39 & 0.71 & 100 & 12.70 & $>200$ & 220 & 240 & 53 & 100 \\
\hline 40 & 0.27 & 99 & 6.70 & 300 & 160 & 240 & 79 & 87 \\
\hline 41 & 0.64 & 116 & 9.63 & 255 & 180 & 240 & -50 & 80 \\
\hline
\end{tabular}


caramelizes to give black solids or solutions. The sodium phosphates have lower solubilities than most other sodium salts. Simple trisodium phosphate is strongly alkaline and would be a product at high pHs only. Other sodium salts like $\mathrm{NaH}_{2} \mathrm{PO}_{4}$ or salts of pyroor triphosphoric acid have low sodium contents and are probably undesirable as components of final waste forms. Some tests with ammonium phosphates did not show any reductions of nitrate.

\subsection{EXAMPLES OF RESULTS}

The measurements and calculations are illustrated by a set of examples. The first 25 tests were equipment checks or tests of caustic feed with no significant reactions, or the test results were compromised by equipment leaks. The examples are, therefore, mostly from Tests 26 through 37.

Test CRON 26. The feed contained $98 \mathrm{mmol}$ of $\mathrm{NaNO}_{3}, 202 \mathrm{mmol}$ of $\mathrm{CH}_{3} \mathrm{OH}$, $140 \mathrm{mmol}$ of acetic acid, $0.18 \mathrm{~g}$ of $\mathrm{CH}_{3} \mathrm{NO}_{2}$, and $1.8 \mathrm{~g}$ of Pt gauze. The feed charged was $45.02 \mathrm{~g}, \mathrm{pH}=1.78$.

The product solution was $42.78 \mathrm{~g}$ and $\mathrm{pH}$ of 4.63 . The solution analyses showed $\mathrm{NO}_{3}{ }^{-} / \mathrm{Na}$ of $0.60 \mathrm{~mol} / \mathrm{mol}$ and $96 \mathrm{mmol}$ of $\mathrm{Na}$ or a decomposition of $40 \%$ of the nitrate.

The excess pressure data (Fig. 3) show that volatile products were formed about 38 to $100 \mathrm{~min}$ at temperatures of 140 to $230^{\circ} \mathrm{C}$. The maximum rate of gas formation was at about $150^{\circ} \mathrm{C}$.

This intended primary reaction was Eq. (9) (Table 1). The observed weight loss of $2.24 \mathrm{~g}$ gives a calculated nitrate decomposition of $4.5 \mathrm{mmol}$ or $46 \%$.

The excess gas pressure (Fig. 4) indicated about $49 \mathrm{mmol}$ of gas, or a nitlrate decomposition of $33 \%$.

Test CRON-30. The feed contained $107 \mathrm{mmol}$ of $\mathrm{NaNO}_{3}, 153 \mathrm{mmol}$ of ammonium acetate, $30 \mathrm{mmol}$ of $\mathrm{CH}_{3} \mathrm{OH}$, and $26 \mathrm{mmol}$ of acetic acid. The total weight of feen charge was $46.6 \mathrm{~g}$, and the $\mathrm{pH}$ was about 5.8 .

The product was $45.15 \mathrm{~g}, \mathrm{pH}=5.00$, and had a $\mathrm{NO}_{3}{ }^{-} / \mathrm{Na}$ ratio of $0.96 \mathrm{~mol} / \mathrm{mol}$. The $\mathrm{NO}_{3}{ }^{-} / \mathrm{Na}$ ratio and a nitrate material balance both show near-zero decomposition of nitrate.

The intended primary reaction was Eq. (7) (Table 1). The observed weight loss would indicate a decomposition of about $33 \mathrm{mmol}$ of nitrate, or $31 \%$. 
The excess pressure data (Fig. 4) show no formation of gaseous products.

Test CRON-32. The feed contained $98 \mathrm{mmol}$ of $\mathrm{Na}$ and $86 \mathrm{mmol}$ of nitrate for a $\mathrm{NO}_{3}{ }^{-} / \mathrm{Na}$ ratio of 0.88 . The feed also contained $22 \mathrm{mmol}$ of formic acid, $130 \mathrm{mmol}$ of $\mathrm{HCHO}$, and water to a total weight of $42.06 \mathrm{~g}$ and a $\mathrm{pH}$ of 3.74 .

The product solution was $38.45 \mathrm{~g}, \mathrm{pH}=4.99$, and had a $\mathrm{NO}_{3}{ }^{-} / \mathrm{Na}$ ratio of 0.39 . The solution analyses showed $90 \mathrm{mmol}$ of sodium.

The excess pressure data (Fig. 3) showed that volatile products were formed from about 40 to $85 \mathrm{~min}$ or 150 to $210^{\circ} \mathrm{C}$. The maximum rate of gas formation was at about $190^{\circ} \mathrm{C}$.

The intended primary reaction was Eq. (5) (Table 1). The observed weight loss of $3.61 \mathrm{~g}$ gives a calculated nitrate decomposition of $82 \mathrm{mmol}$, or $95 \%$.

The excess gas pressure indicated about $47 \mathrm{mmol}$ of gas, or a nitrate decomposition of $55 \%$.

\section{REFERENCES}

1. Paul A. Haas, U.S. Patent 4,225,455 (September 30, 1980).

2. A. J. Mattus et al., A Low-Temperature Process for the Denitration of Hanford Single-Shell Tank, Nitrate-Based Waste Utilizing the Nitrate to Ammonia and Ceramic (NAC) Process, ORNL/TM-12245, Oak Ridge National Laboratory, Oak Ridge, TN, October 1993.

\section{ACKNOWLEDGMENT}

The initial tests with conditions intended to convert $\mathrm{NaNO}_{3}$ to $\mathrm{NaOH}$ were mostly performed by L. K. McGinnis as an ORNL summer employee. 
ORNL/TM-12800

\section{INTERNAL DISTRIBUTION}

1. E. C. Beahm

2. J. M. Begovich

3. J. T. Bell

4. C. H. Brown

5. C. H. Byers

6. E. D. Collins

7. A. G. Croff

8. S. M. Crosley

9-13. P. A. Haas

14. T. S. Kress
15. L. E. McNeese

16. R. E. Norman

17. B. D. Patton

18. D. R. Reichle

19. J. C. Rudloph

20. E. L. Youngblood

21. Central Research Library

22. ORNL-Y-12 Technical Library Document Reference Section

23-24. Laboratory Records

25. ORNL Patent Section

\section{EXTERNAL DISTRIBUTION}

26. Office of Assistant Manager for Energy Research and Development, DOE-OR, P.O. Box 2001, Oak Ridge, TN 37831

27-28. Office of Scientific and Technical Information, P.O. Box 2001, Oak Ridge, TN 37831 

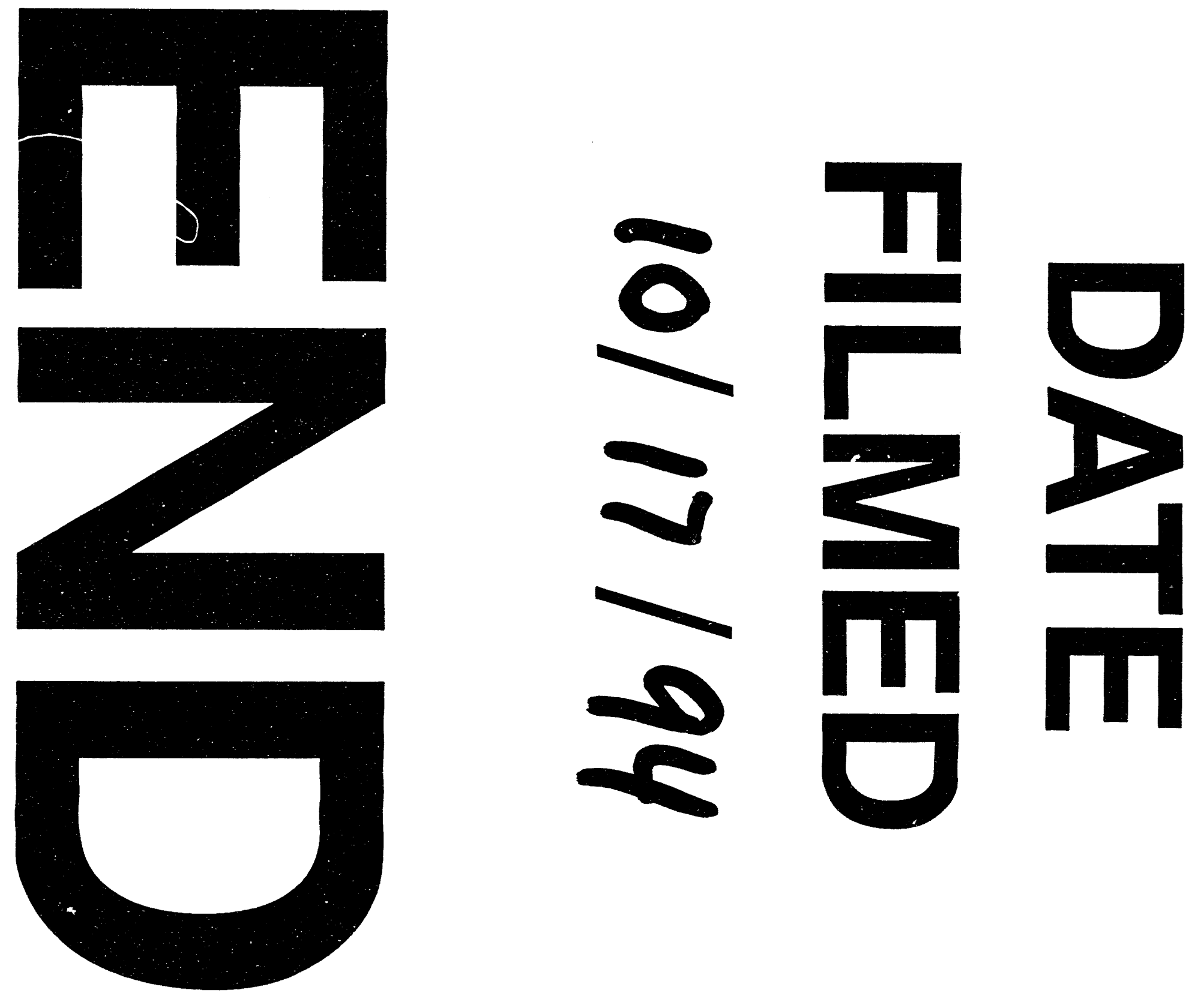
